\title{
Eco-friendly and Efficient Synthesis, Characterisation and Antibacterial Studies of Unsymmetrical Bidentate Schiff Bases and their Zn(II) Complexes
}

\author{
K.P. SRIVASTAVA ${ }^{*}$, ANURADHA SINGH and SURESH KUMAR SINGH \\ Department of Chemistry, Ganga Singh College, J.P.University, Chapra-841301, Bihar, India. \\ ${ }^{*}$ Corresponding author E-mail: gscdrkpsritprin@gmail.com \\ http://dx.doi.org/10.13005/ojc/300339
}

(Received: June 01, 2014; Accepted: 13 July, 2014)

\begin{abstract}
A rapid, efficient, clean and environmentally benign exclusive synthesis of Schiff bases as new ligands and their complexes with $\mathrm{Zn}(\mathrm{II})$ have been developed using condensation of pyridoxal with amoxicillin $\left(\mathrm{L}^{1}\right)$, cephalexin $\left(\mathrm{L}^{2}\right)$, sulphamethoxazole $\left(\mathrm{L}^{3}\right)$ and trimethoprim $\left(\mathrm{L}^{4}\right)$ efficiently in analcoholic suspension medium using alkali catalyst with excellent yields under microwaves irradiation. This method provides several advantages such as environmental friend liness, simple work-up procedure, short reaction times, non-hazardous and excellent yield of products. The results are compared with conventional methods for their yield and reaction time. The Schiff base ligands and the complexes were characterized by micro-analytical, thermo-gravimetric, magnetic and spectroscopic studies.All the Schiff bases were bidentate (NO donor) ligands. All complexes were found to be six co-ordinate dihydrates and $\mathrm{ML}_{2}[1: 2$ (metal: ligand) ratio] type. The complexes are coloured and stable in air. All the complexes under investigation possess antibacterial activity. The antibacterial activity showed the following trend:
\end{abstract}

$$
\text { Zn(II)-complexes }>\text { Schiff base ligands }>\text { Parent drugs. }
$$

Key words:Schiff bases; Coordination compounds;Microwave irradiation; Antibacterial activity; Zinc

\section{INTRODUCTION}

Schiff base ligands have been widely studied in the field of coordination chemistry for analytical, physical, and biochemical purposes mainly due to their facile syntheses, easily availability, electronic properties and good solubility in common solvents and they easily form stable complexes with most transition metal ions ${ }^{1-6}$. A large number of Schiff bases and their metal complexes have been found to possess important biological and catalytic activity. Due to their great flexibility and diverse structuralaspects, a wide range of Schiff bases have been synthesized conventionally and their complexation behavior was studies. The development of the field of bioinorganic chemistry has increased the interest in Schiff base complexes, since it has been recognized that 
many of these complexes may serve as models for biologically important speciesand were investigated for antifungal, antimicrobial, anti- bacterial,antiinflammatory, anti-convulsant, anticanceractivities ${ }^{7-11}$.

Zinc is an essential trace element, necessary for plants, animals, and microorganisms. Zinc is found in nearly 100 specific enzymes (other sources say 300) [12-14], serves as structural ions in transcription factors and is stored and transferred in metallothioneins. It is "typically the second most abundant transition metal in organisms" after iron and it is the only metal which appears in all classes. As environmental consciousness in chemical research and industry has increased, efficient, economic and clean procedures have received increased attention in recent years. The development of a simple and effective method, using an environmentally friendly approach as well as an economical process is in great demand in coordination chemistry. Recent advances in technology have now made microwave energy a more efficient means of heating reactions. Chemical transformations that took hours, or even days, to complete their organic reaction, can now be accomplished in minutes. Microwave irradiation is well known to promote the synthesis of a variety of organic and inorganic compounds, where chemical reactions are accelerated because of selective absorption of microwave by polar molecules ${ }^{15-19}$.

Microwave syntheses of coordination and organometallic compounds are presented by relatively a small number of reports in the available literature in comparison with inorganic and organic synthesis. Prompted by the above mentioned biological and multifunctionalactivities of Schiff bases and their metal complexes as well as the utility of microwave irradiation in inorganic syntheses, in continuation of our efforts to synthesize novel heterocyclic molecules of biological importance ${ }^{20-22}$, we envisaged a mild base mediated synthesis of some new Schiff bases of pyridoxal with amoxicillin $\left(L^{1} H\right)$, cephalexin $\left(L^{2} H\right)$, sulphamethoxazole $\left(L^{3} H\right)$ and trimethoprim $\left(\mathrm{L}^{4} \mathrm{H}\right)$ using alcoholic medium as a recyclable eco-friendly solvent under microwave irradiation without using any non-ecofriendly organic solvents and the products were isolated simply by crystallization.In this article, we report zinc (II) complexes of the unsymmetrical ligands and their antibacterial studies. Single crystal of the complexes could not be isolated from any solutions. However, analytical, spectroscopic, and magnetic data enable us to propose possible structures.

\section{EXPERIMENTAL}

\section{Materials and Methods}

All the used chemicals and solvents were of Anal $\mathrm{R}$ grade. All the reagents used for the preparation of the Schiff bases were obtained from Sigma Aldrich. Metal salts were obtained from Loba Chemie and original drugs were obtained from Glaxo SmithKline, India and were used without furtherpurification. Melting points were determined on a Mel-Temp melting point apparatus and are uncorrected. All compounds were analysed satisfactorily for $\mathrm{C}, \mathrm{H}$ and $\mathrm{N}$ using Carl-Ebra 1106 elemental analyser in micro analytical laboratory. Thin layer chromatography (TLC) was carried out on silica gel plates (FlukaKieselgel, $0.2 \mathrm{~mm}$ thickness) and the plates were scanned under $254 \mathrm{~nm}$ ultraviolet light. Magnetic susceptibility measurements of the metal complexes in the solid state were determined by a Gouy balance at room temperature. Electronic spectra (in DMSO solvent) in the UV-Visible range were recorded on Perkin Elmer Lambda-2B-spectrophotometer. Molar conductance measurements were conducted using $10^{-3} \mathrm{M}$ solution of the complexes in DMSO on ElicoCM 82 Conductivity Bridge at room temperature. FT-IR spectra were recorded in $\mathrm{KBr}$ medium and Nujol mull techniques on a Perkin Elmer RX1 spectrophotometer in wave number region 4000-400 $\mathrm{cm}^{-1}$. Thermogravimetric analysis was carried out under atmospheric condition with a heating rate 10 ${ }^{\circ} \mathrm{C}$ min $^{-1}$ on TGA Q500 universal V4.5A TA instrument from ambient to $773 \mathrm{~K}$. The solid state electrical conductivity has been measured by impedance spectroscopic method using HIOKI 3532-50 LCR Hitester at fixed frequency $1 \mathrm{KHz}$ in the temperature range of 298-473 K. Microwave assisted synthesis were carried out in open glass vessel on a modified microwave oven model 2001 ETB with rotating tray and a power source $230 \mathrm{~V}$, microwave energy output $800 \mathrm{~W}$ and microwave frequency $2450 \mathrm{MHz}$. A thermocouple used to monitor the temperature inside the vessel of the microwave. The microwave reactions were performed using on/off cycling to control the temperature.Completion of reaction was monitored by performing TLC and melting point. 


\section{Synthesis of Ligands}

The equimolar (1:1) ratio of methanolic solution of drug and methanolic solution of pyridoxal hydrochloride were mixed thoroughly and $0.1 \%$ methanolic $\mathrm{KOH}$ was added to adjust the $\mathrm{pH}$ of the solution within 7-8 and was then irradiated in the microwave oven by taking $3-4 \mathrm{ml}$ solution. The reaction was completed in a short time (1-2 min) with higher yields showing clear coloured solution. The Schiff base ligands were isolated by crystallization after volume reduction by evaporation. The crystalline products were dried under vacuum or reduce pressure under anhydrous $\mathrm{CaCl}_{2}$ and kept in a desiccator till further use. The progress of the reaction and purity of the products were monitored by TLC using silica gel G (yield: 73-89\%).

\section{Synthesis of metal complexes}

The methanolic solution of ligand and the metal salt were mixed thoroughly in 1:2 (metal : ligand) ratio and $0.1 \%$ methanolic $\mathrm{KOH}$ was added to adjust the $\mathrm{pH}$ of the solution within 7-8 and was then irradiated in the microwave oven by taking 3-4 ml solution. The reaction was completed in a short time (2-5 min.) with higher yields. The resulting light yellow product was then recrystallized with methanol and ether and finally dried under reduced pressure over anhydrous $\mathrm{CaCl}_{2}$ in a desiccator. The progress of the reaction and purity of the product was monitored by TLC using silica gel G (yield: 75-87\%) (scheme-1).

\section{Biological Evaluation}

The in vitro biological activity of the investigated Schiff base ligands $\left(\mathrm{L}^{1} \mathrm{H}-\mathrm{L}^{4} \mathrm{H}\right)$ and their metal complexes was tested against three bacteria Escherichia coli, P.aeruginosaand Staphylococcus aureus by disc diffusion method ${ }^{23}$ using nutrient agar as medium and streptomycin as control. The minimum inhibitory concentration was determined using the disc diffusion technique ${ }^{24}$.

\section{RESULTS AND DISCUSSION}

As a result of microwave assisted synthesis, it was observed that the reaction was completed in a short time with higher yields compared to the conventional method. In the microwave method homogeneity of reaction mixture was increased by the rotating of reaction platform tray. The confirmation of the results was also checked by the repeating of the synthesis process. Comparative study results obtained by microwave assisted synthesis; versus conventional heating method is that some reactions which required 0.5-3 h. by conventional method, was completed within 2-5 min. by the microwave irradiation technique, yields have been improved from $35-48 \%$ to $73-87 \%$.

All the metal complexes are coloured, solid and stable towards air and moisture at room temperature. They do not possess sharp melting points and decompose on heating at high temperature (at about $>563 \mathrm{~K}$ ). The complexes are insoluble in common organic solvents butsoluble in DMF and DMSO.The comparative results of conventional and microwave methods, analytical data of the compounds, together with their physical properties are consistent with proposed molecular formula are given in Table-1. The micro-analytical data suggest that the composition of all the metal complexes corresponds to 1:2 (metal: ligand) stoichiometry and have one or two water molecules i.e. hydrated. The observed molar conductance values $\left(10.2-32.5 \mathrm{ohm}^{-1} \mathrm{~cm}^{2} \mathrm{~mole}^{-1}\right)$ are too low to account for any dissociation of the complexes in DMF at room temperature, indicating non-electrolytic nature of the complexes ${ }^{25}$.

\section{IR Spectral Studies}

The data of the IR spectra of investigated Schiff base ligands and their metal complexes are listed in Table 2.The IR spectra of the complexes were compared with those of the free ligand in order to determine the involvement of coordination sites in chelation. Characteristic peaks in the spectra of the ligand and complexes were considered and compared. The FT-IR spectra of the investigated complexes contained all the absorption bands from the ligands and some new absorption bands indicative of coordination of the ligands with metal ion through $\mathrm{N}$ and $\mathrm{O}$. The spectra of these complexes exhibited a broad band around 3490-3505 $\mathrm{cm}^{-1}$ which is assigned to water molecules, $v(\mathrm{OH})$, associated with the complexes. The coordinated water exhibited, in addition to these modes, the $v_{r}\left(\mathrm{H}_{2} \mathrm{O}\right)$, rocking near 845-890, $\mathrm{cm}^{-1}, v_{w}\left(\mathrm{H}_{2} \mathrm{O}\right)$, wagging near $540-550 \mathrm{~cm}^{-1} 26$. The FT-IR spectra of all the ligands contained a band at $1620-1632 \mathrm{~cm}^{-1}$, $v(\mathrm{C}=\mathrm{N})$, which shifted slightly to a higher value in 


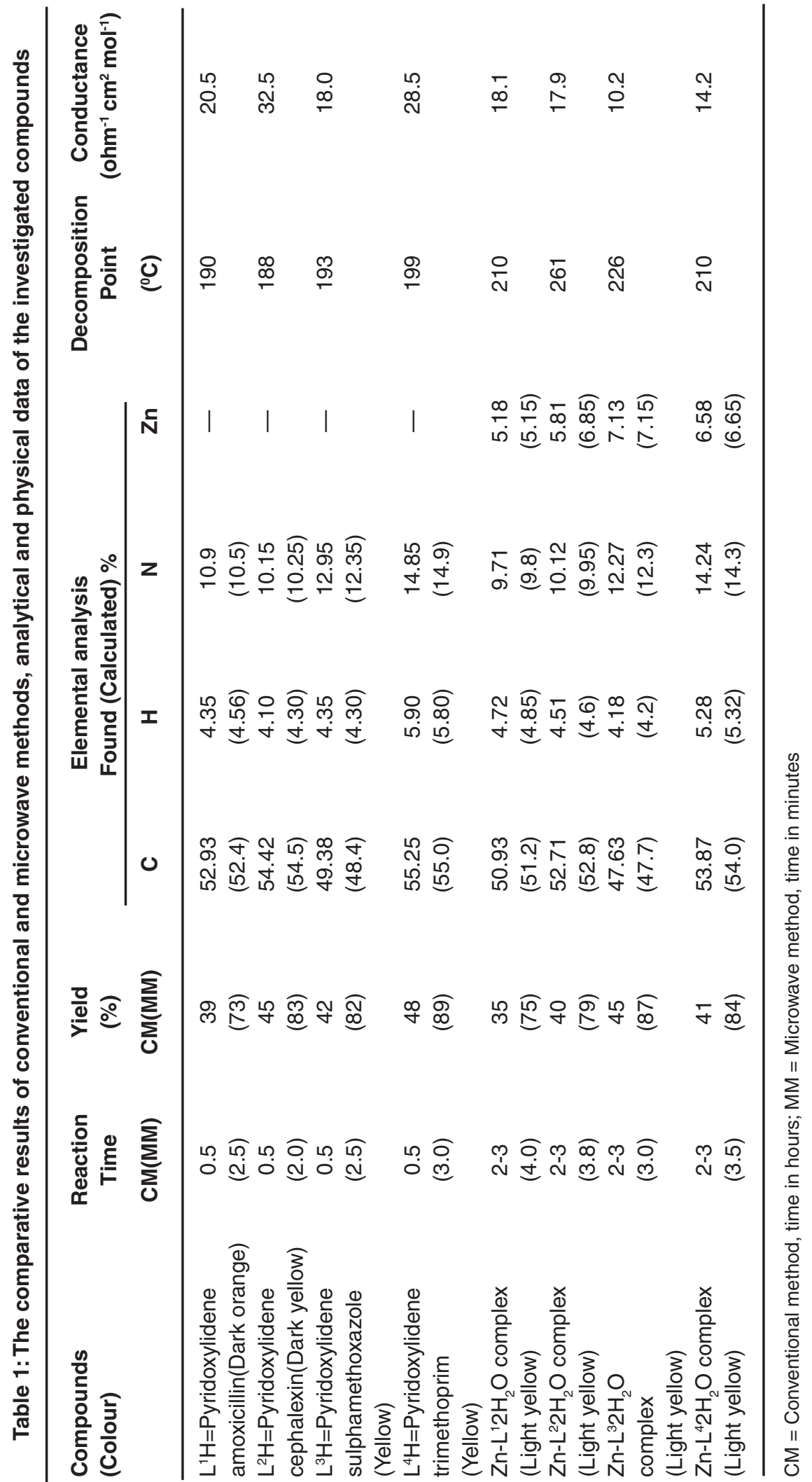


all the complexes suggesting that the ligands are coordinated through $-\mathrm{C}=\mathrm{N}-{ }^{27}$. The absorption due to carboxylic group did not change in the spectra of complexes indicating that the carboxylic groups are not involved in coordination with the metal ion. New absorption bands, $v(\mathrm{MN})$ and $v(\mathrm{MO})$, appeared at $435-460 \mathrm{~cm}^{-1}$ and $330-355 \mathrm{~cm}^{-1}$ respectively, in the

Table 2: Observed IR bands $\left(\mathrm{cm}^{-1}\right)$ of Schiff base ligands and their $\mathrm{Zn}$-complexes

\begin{tabular}{lcccccccc}
\hline Compound & $v(\mathbf{O}-\mathbf{H})$ & $v(\mathbf{C}=\mathbf{N})$ & $\rho_{r}\left(\mathbf{H}_{2} \mathbf{O}\right)$ & $\rho_{w}\left(\mathbf{H}_{2} \mathbf{O}\right)$ & $\delta(\mathbf{C O})$ & $\tau(\mathbf{C O})$ & $v(\mathbf{M}-\mathbf{N})$ & $v(\mathbf{M}-\mathbf{O})$ \\
\hline Pyridoxylideneamoxicillin & 3510 & 1620 & 890,850 & 540 & 745 & 570 & - & - \\
Pyridoxylidenecephalexin & 3515 & 1630 & 875,845 & 535 & 740 & 580 & - & - \\
Pyridoxylidenesulphamethoxazole & 3505 & 1620 & 889,855 & 530 & - & - & - & - \\
Pyridoxylidenetrimethoprim & 3490 & 1632 & 890,850 & 538 & - & - & - & - \\
$\mathrm{Zn}-\mathrm{L}^{1} 2 \mathrm{H}_{2} \mathrm{O}$ complex & 3490 & 1628 & 890,845 & 540 & 745 & 575 & 454 & 350 \\
$\mathrm{Zn}-\mathrm{L}^{2} 2 \mathrm{H}_{2} \mathrm{O}$ complex & 3483 & 1632 & 885,850 & 540 & 740 & 578 & 460 & 355 \\
$\mathrm{Zn}-\mathrm{L}^{3} 2 \mathrm{H} 2 \mathrm{O}$ complex & 3465 & 1635 & 885,860 & 550 & - & - & 435 & 330 \\
$\mathrm{Zn}-\mathrm{L}^{4} 2 \mathrm{H}_{2} \mathrm{O}$ complex & 3463 & 1633 & 875,850 & 545 & - & - & 448 & 345 \\
& & & & & & & &
\end{tabular}

Table 3: Electronic spectral bands,magnetic moments and proposed geometry of the $\mathrm{Zn}$ (II) complexes

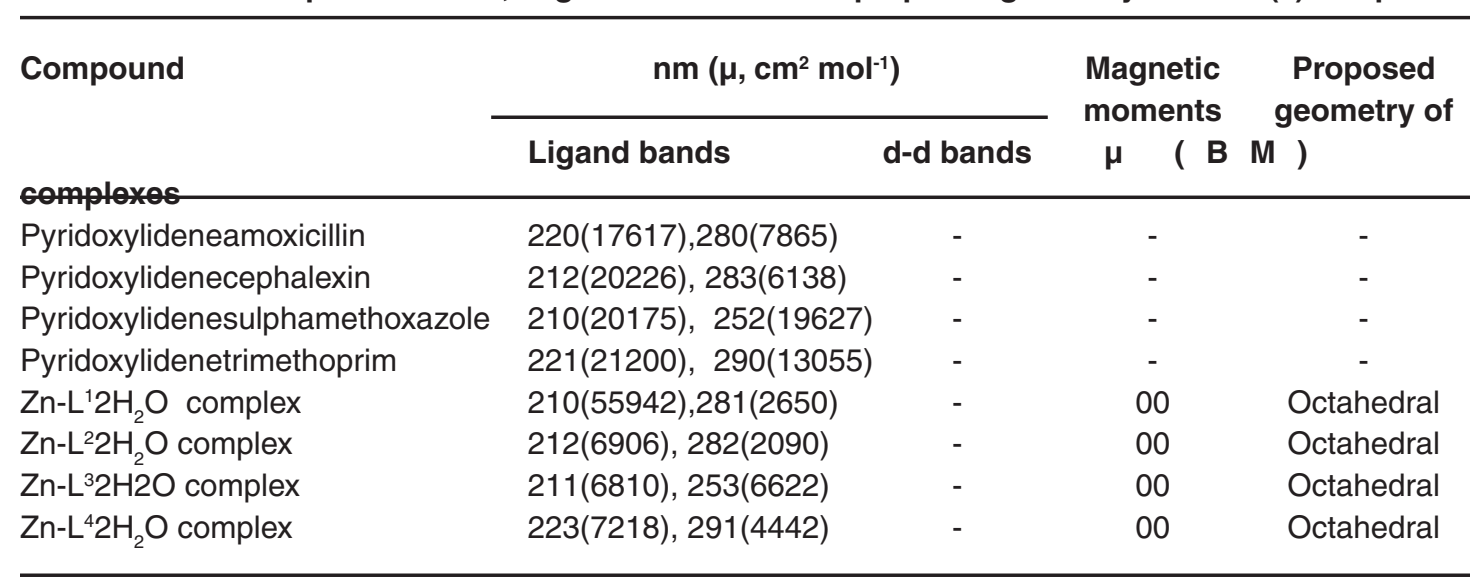

Table 5: Thermal analysis data of the $\mathrm{Zn}(\mathrm{II})$ complexes

\begin{tabular}{|c|c|c|c|c|c|c|}
\hline \multirow[t]{2}{*}{ Complexes } & \multirow{2}{*}{$\begin{array}{c}\text { Temperature } \\
\text { range }\left({ }^{\circ} \mathrm{C}\right)\end{array}$} & \multirow[t]{2}{*}{ Stage } & \multirow{2}{*}{$\begin{array}{l}\text { TG Wt. } \\
\text { Loss, \% } \\
\text { Found }\end{array}$} & \multirow{2}{*}{$\begin{array}{l}\text { DTA Temp. } \\
\text { Peak, }\left({ }^{\circ} \mathrm{C}\right)\end{array}$} & \multicolumn{2}{|c|}{ Evolved Moiety } \\
\hline & & & & & Formula & $\begin{array}{c}\text { Mass } \\
\text { calculated } \\
\%\end{array}$ \\
\hline $\mathrm{Zn}-\mathrm{L}^{1} \cdot 2 \mathrm{H}_{2} \mathrm{O}$ & $100-300$ & 1 & 3.31 & 392.66(Exo) & $2 \mathrm{H}_{2} \mathrm{O}$ & 3.66 \\
\hline complex ${ }^{2}$ & $300-500$ & 2 & 46.25 & 488.69(Endo) & Ligand & 47.00 \\
\hline $\mathrm{Zn}-\mathrm{L}^{2} \cdot 2 \mathrm{H}_{2} \mathrm{O}$ & $100-150$ & 1 & 3.43 & 392.66(Exo) & $2 \mathrm{H}_{2} \mathrm{O}$ & 3.88 \\
\hline complex & $150-500$ & 2 & 47.46 & 488.69(Endo) & Ligand & 46.98 \\
\hline $\mathrm{Zn}-\mathrm{L}^{3} \cdot \mathrm{H}_{2} \mathrm{O}$ & $100-300$ & 1 & 2.82 & 219.53(Endo) & $2 \mathrm{H}_{2} \mathrm{O}$ & 3.62 \\
\hline complex & $300-500$ & 2 & 46.82 & 373.63(Exo) & Ligand & 46.53 \\
\hline $\mathrm{Zn}-\mathrm{L}^{4} \cdot 2 \mathrm{H}_{2} \mathrm{O}$ & $100-200$ & 1 & 4.15 & 290.42(Exo) & $2 \mathrm{H}_{2} \mathrm{O}$ & 4.05 \\
\hline complex & $200-500$ & 2 & 45.26 & 383.59(Exo) & Ligand & 46.23 \\
\hline
\end{tabular}


Table-6: Minimum inhibitory concentrations of investigated ligands, their Cu-complexes and the parent drugs (in $\mu \mathrm{gmL}^{-1}$ )

\begin{tabular}{lccc}
\hline \multirow{2}{*}{ Compound } & \multicolumn{3}{c}{ MICs (in $\mathbf{\mu g m L} \mathbf{L}^{-1}$ ) } \\
\cline { 2 - 4 } & E.coli & S.aureus & P.aeruginosa \\
\hline Amoxicillin & 95 & 13 & $>300$ \\
Cephalexin Sodium & 99 & 10 & $>300$ \\
Sulphamethoxazole & 100 & 65 & $>300$ \\
Trimethoprim & 0.5 & 0.7 & $>300$ \\
Pyridoxylideneamoxicillin & 73 & 10 & $>300$ \\
Pyridoxylidenecephalexin & 51 & 5.5 & $>300$ \\
Pyridoxylidenesulphamethoxazole & 76 & 46 & $>300$ \\
Pyridoxylidenetrimethoprim & 0.4 & 0.5 & $>300$ \\
Zn- $\mathrm{L}^{1} .2 \mathrm{H} 2 \mathrm{O}$ complex & 9.8 & 6.5 & $>200$ \\
Zn- $\mathrm{L}^{2} .2 \mathrm{H}_{2} \mathrm{O}$ complex & 7.8 & 4.5 & $>200$ \\
Zn- $\mathrm{L}^{3} .2 \mathrm{H} 2 \mathrm{O}$ complex & 9.5 & 5.8 & $>200$ \\
Zn- $\mathrm{L}^{4} .2 \mathrm{H}_{2} \mathrm{O}$ complex & 0.06 & 0.25 & $>200$ \\
\hline
\end{tabular}

spectra of the investigated complexes indicating coordination of the ligands through $\mathrm{N}$ and $\mathrm{O}$.

The important bands along with their assignments are listed in table-2.The assignments were made by comparison with related Schiff base complexes $^{28-29}$.<smiles>Cc1ncc(CO)c(C=NC(C(=O)NC2SC3(C)[C@@H](C)N(C2=O)[C@@H]3C(=O)O)c2ccc(O)cc2)c1O</smiles>

$\mathrm{L}^{1} \mathrm{H}=$ Pyridoxylideneamoxicillin<smiles>Cc1cc(NS(=O)(=O)c2ccc(N=COc3c(N=[OH+])ccc(O)c3O)cc2)no1</smiles>

$\mathrm{L}^{3} \mathrm{H}=$ Pyridoxylidenesulphamethoxazole

\section{Electronic Spectral Studies}

The electronic absorption spectra show that when drug substances and pyridoxal were mixed together, the imine formation occurred which was indicated by colouration of the solution and development of an absorption band in the visible region ${ }^{30}$.<smiles>Cc1ncc(CO)c(C=NCC(=O)[C@H]2CC(=O)N3C(C(N)=O)C(C)CS[C@@H]23)c1O</smiles>

$\mathrm{L}^{2} \mathrm{H}=$ Pyridoxylidenecephalexin<smiles>[CH]c1ccc(C#[Hg])c([Se]=Nc2ncc(Cc3cc(OC)c(OC)c(OC)c3)c(N)n2)c1[CH]</smiles>

$\mathrm{L}^{4} \mathrm{H}=$ Pyridoxylidenetrimethoprim

Fig. 1:Structure Formulae of the investigated ligands 


$$
\begin{aligned}
& \text { MWI } \\
& \mathrm{Zn}\left(\mathrm{CH}_{3} \mathrm{COO}\right)_{2} \mathrm{H}_{2} \mathrm{O}+2 \mathrm{LH} \\
& \text { 2-5 minutes Light yellow } \\
& \mathrm{Zn}\left[\mathrm{L}_{2} 2 \mathrm{H}_{2} \mathrm{O}\right]
\end{aligned}
$$

\section{Scheme 1: Synthesis of metal complexes}<smiles>Cc1ncc(CO)c(O[N+]2(C)CNc3c(CO)cnc(C)c3O[Te]2(O)O)c1CO</smiles>

Fig. 2: Proposed octahedral structure of $\mathrm{Zn}-\left(\mathrm{L}^{1}\right)_{2} \cdot 2 \mathrm{H}_{2} \mathrm{O}, \mathrm{Zn}-\left(\mathrm{L}^{2}\right)_{2} \cdot 2 \mathrm{H}_{2} \mathrm{O}$ and $\mathrm{Zn}-\left(\mathrm{L}^{3}\right)_{2} \cdot 2 \mathrm{H}_{2} \mathrm{O}$ complexes

In these spectra, there is an intense band at $252-291 \mathrm{~nm}$ which is assigned to a $\pi-\pi^{*}$ transition originating in the phenyl ring ${ }^{31}$. The bands in the 210$223 \mathrm{~nm}$ range, by analogy with LM, are attributed to a $\pi-\pi^{*}$ transition originating in the $-\mathrm{CH}=\mathrm{N}$ chromophore.The important electronic spectral bands along with their assignments of the isolated ligands and the complexes under investigation are listed in table-3.

\section{Magnetic Moment Studies}

The magnetic moments of the complexes under investigation were observed as expected and found zero which is indicative of diamagnetic nature of these investigated complexes.

\section{Thermo-analytical Studies}

The thermal decomposition reactions of investigated complexes have been studied in $\mathrm{N}_{2}$ atmosphere using TG and DTA techniques. The TG weight loss data and DTA peak temperatures are presented in table-4.

The complexes begin to lose weight around $353 \mathrm{~K}$ show the presence of moisture and around $393 \mathrm{~K}$ suggesting the presence of coordinated water; it is the dehydration stage which water molecules are eliminated. There was a weight

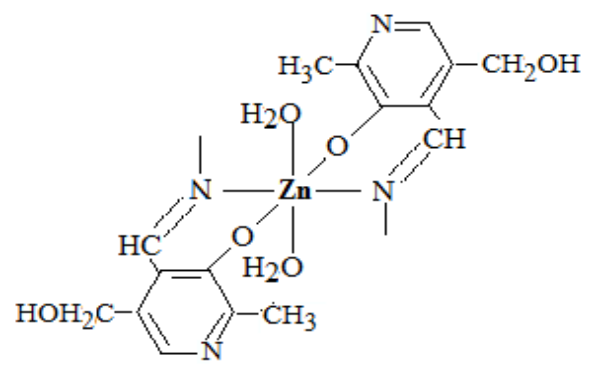

Fig. 3: Proposed octahedral structure of $\mathrm{Zn}-\left(\mathrm{L}^{4}\right)_{2} \cdot \mathbf{2} \mathrm{H}_{2}$ Ocomplex loss equivalent to one water molecule in case of pyridoxylidenesulphamethoxazole- $\mathrm{Zn}(\mathrm{II})$ and two water molecules in the case of other complexes around $393 \mathrm{~K}$ showing that the water is coordinated. From 473 to $773 \mathrm{~K}$ a sharp decrease in weight indicated a loss of one of the Schiff base ligands from the complexes.

In general the thermal decomposition of complexes may be considered by the following equation [32]:

$$
\begin{aligned}
\mathrm{ML}_{2} \mathrm{xH}_{2} \mathrm{O} & \rightarrow \mathrm{ML}_{2}+\mathrm{xH}_{2} \mathrm{O} \\
\mathrm{ML}_{2} & \rightarrow \mathrm{ML}+\mathrm{L}
\end{aligned}
$$

The DTA curves show different peaks in the range of 451-663K. The first (endothermic) peak in the range of $451-497 \mathrm{~K}$ corresponds to the loss of water molecules. The second (exothermic) peak in these complexes in the range of $647-658 \mathrm{~K}$ is assigned to the loss of one of the Schiff base ligands.

\section{Proposed Structures}

On the basis of the above observations, it is tentatively suggested that $\mathrm{Zn}$ (II) investigated complexes show an octahedral geometry [Fig. 2\& 3] in which the Schiffbases act as bidentate [N \& O donor] ligands. 


\section{Anti-bacterial Activity}

The difference in anti-bacterial activities of the investigated complexes, ligands and their parent drugs were studied and the results are presented in table-6

The cursory view of the data indicates the following trend in antibacterial activity of the substances under investigation: parent drugs

$\mathrm{Zn}$ (II)-complexes < Schiff base ligands <

All the $\mathrm{Zn}(\mathrm{II})$-complexes and Schiff base ligands under investigation were more active than the parent drugs against $E$. coli and S. aureus. All the $\mathrm{Zn}$ (II)-complexes with the Schiff bases derived from cephalexin showed substantially enhanced activity against P.aeruginosa as compared with the parent drug.

\section{CONCLUSION}

In this report, we described coordination chemistry of unsymmetrical Schiff bases as new ligands and their complexes with $\mathrm{Zn}$ (II) which have been synthesized using condensation of pyridoxal and amoxicillin $\left(L^{1}\right)$, cephalexin $\left(L^{2}\right)$, sulphamethoxazole $\left(L^{3}\right)$ and trimethoprim $\left(L^{4}\right)$ efficiently in analcoholic suspension medium using alkali catalyst with excellent yields under microwaves irradiationand characterized by various physicochemical and spectral analyses. In the result of microwave assisted synthesis, it has been observed that the reaction time decreased from hours to minutes and availability of the product within better yields compared to the classical method. The synthesized Schiff base ligands coordinated with the $\mathrm{Zn}$ (II) ion in a bidentate mannerthrough the phenolic $\mathrm{O}$ and azomethine $\mathrm{N}$. The ${ }^{1} \mathrm{H}-\mathrm{NMR}$ data suggest that all theSchiff base ligands deprotonated after complexation. The thermal data showdegradation pattern of the complexes. Thermo-gravimetric studied of the complexes also helpedto characterize the complexes. Antimicrobial data suggests that the metal complexes are betterantibacterial agents as compared to their ligands. The compounds also inhibit thegrowth of bacteria to a greater extent as the concentration is increased. The antibacterial activity showed the following trend:

$\mathrm{Zn}$ (II)-complexes < Schiff base ligands < parent drugs

Inconclusion, we have described here an efficient and environmentally benign synthesis of Schiff base ligands and their corresponding Zn(II) complexes under microwave irradiation using water and methanol as solvents. Further, this method is simple, mild and ecofriendly from green chemistry point of view.

\section{REFERENCES}

1. R. Pagadala; P.Ali; J.S. Meshram, J. Coord. Chem., 2009, 62(24), 4009-4017.

2. V.K. Yadav, N. Kumari and Lallan Mishra, Indian J. Chem., 2011, 50 A (8), 1035-1042.

3. M. Asadi, S. Esmaielzadeh, K. Mohammadi, Phosphorus, Sulfur, and Silicon, 2010 185, 1445.

4. V.P. Daniel, B. Murukan, B.S. Kumari, K. Mohanan, Spectrochim. Acta. Part A., 2008, 70, 403.

5. B.T. Thaker, K.R. Surati, C.K. Modi, Russ. J. Coord. Chem., 2008, 34, 25.

6. K.R. Surati, B.T. Thaker, G.R. Shah, Synth. React. Inorg. Met-Org. Nano-Met. Chem., 2008, 38, 272.

7. A.A. Nejo, G.A. Kolawole, A.O. Nejo, J. Coord.
Chem., 2010, 63, 4398.

8. R. Vafazadeh, M. Kashfi, Bull. Korean Chem. Soc., 2007, 28, 1227.

9. N. Raman, J. Dhaveethuraja, A. Sakthivel, J. Chem. Sci., 2007, 119, 303.

10. L.C. Nathan, J.E. Koehne, J.M. Gilmore, K.A. Hannibal, W.E. Dewhirst, T.D. Mai, Polyhedron., 2003, 22, 887.

11. K.C.Gupta, A.K Sutar, Coord. Chem. Rev. 2008, 52 (12-14), 1420-1450.

12. K. M. Hambidge, N. F. Krebs, "Zinc deficiency: a special challenge". J. Nutr. 2007, 137(4): 1101-5.

13. A. S. Prasad, British Medical Journal, 2003; 326 (7386): 409-10.

14. Wolfgang Maret, Lucia Banci, (Ed.). 
Metallomics and the Cell: Metal lons in Life Sciences, 2013, 12, Springer.

15. V. Polshettiwar, Aqueous Microwave Assisted Chemistry: Synthesis and Catalysis, 2010, Royal Society of Chemistry, ISBN 978-1 84973-038-9, Cambridge, UK.

16. P. Ali; P.Ramakanth; J.S. Meshram, J. Coord. Chem., 2010, 63(2), 323-329.

17. B.L. Hayes, Recent Advances in MicrowaveAssisted Synthesis, Aldrich Chimica Acta, 2004, 37(2), 66-76.

18. N. E. Leadbeater, Microwave Heating as a Tool for Sustainable Chemistry, 2010, CRC Press,Boca Raton, USA.

19. B. L. Hayes, Microwave Synthesis: Chemistry at the Speed of Light, 2002, CEM, USA.

20. K.P.Srivastava et al. Der Chemica Sinica, 2011, 2(2), 66-76.

21. K.P.Srivastava et al. ISOR Journal of Applied Chemistry; 2014, 7(4), 16-23.

22. K.P.Srivastava et al. American International Journal of Research in Science, Technology, Engineering \& Mathematics, 2014, 6(3), 286-
292

23. A.W. Bauer, W.M.M. Kibry., et al Am. J. Clin. Pathol. 1966, 45, 496.

24. A.Chaudhary, R.V Singh, J. Inorg. Biochem. 2004, 98, 1712.

25. R.L. Dutta; A. Syamal, Elements of Magneto Chemistry, $2^{\text {nd }}$ ed. Affiliated East West Press, New Delhi, 1993.

26. A.Chaudhary, R.V Singh, J. Inorg. Biochem. 2004, 98, 1712.

27. W.J. Geary, Coord. Chem. Rev., 1971, 7, 81.

28. K Nakamoto, Infrared and Raman Spectra of Inorganic and Coordination Compounds, $5^{\text {th }}$ ed. John Wiley, Sons, Part A, B, New York, 1998.

29. M.S.Iqbal, S.J.Khurshid, M.Z.Iqbal; Canad. J.Chem. 1993, 71, 629.

30. B.Bosnich, J. Am. Chem. Soc., 1968, 90, 627.

31. R.S.Dowing, F.L.Urbach, J.Am. Chem. Soc., 1969, 91, 5977.

32. M.Arif, S.Rehman, K.Musad, M.Arshad, N.Arshad, Turk.J.Chem. 2001, 255, 73. 